Article

\title{
The Effect of Personal Value on CSV (Creating Shared Value)
}

\author{
Jeongho Koo ${ }^{1}$, Suhyun Baek ${ }^{2}$ (D) and Sunah Kim ${ }^{3, *}$ \\ 1 Department of Business Administration, Kumoh National Institute of Technology, Gumi 39177, Korea, \\ jhk2001@kumoh.ac.kr \\ 2 Graduate school of Consulting, Kumoh National Institute of Technology, Gumi 39177, Korea; \\ viridian34@naver.com \\ 3 Department of Industrial Engineering, Kumoh National Institute of Technology, Gumi 39177, Korea \\ * Correspondence: sun@kumoh.ac.kr
}

Received: 4 June 2019; Accepted: 19 June 2019; Published: 21 June 2019

\begin{abstract}
The purpose of this study is to reveal the effect of personal value as a part of creating shared value (CSV). We extracted factors of personal value through a literature review. Personal value consists of social commitment, self-actualization, goal setting, and solidarity. Self-actualization is the universal motivation of the individual, goal setting is the basis for the occurrence of action, and solidarity is the relationship factor that defends competition and personalization. This study was conducted on three hypotheses. Hypothesis 1 is that self-actualization will have an effect on CSV. Hypothesis 2 is that goal setting will have an effect on CSV. Hypothesis 3 is that solidarity will have an effect on CSV. The proxy of CSV is social commitment. We examine the effects of these personal values on CSV by surveying 557 university students. This study applied the regression model to test the hypotheses. The empirical results are as follows. CSV increases when we are more self-actualized. Goal setting positively affects CSV. CSV goes up as we have many relationships with organizations and are more cooperative in work. This study suggests the important elements of personal values in a university setting for CSV, and enables setting the direction of the education by setting the index of the attitude to increase the value of the individual in CSV.
\end{abstract}

Keywords: CSV; personal value; self-actualization; goal setting; solidarity

\section{Introduction}

Since the Industrial Revolution, tremendous economic growth has been based on the indiscreet development of companies. Companies' efforts to survive in the market have led to fierce competition, which has created a competitive atmosphere for businesses as well as society as a whole. Although these competitive developments have led to growth in the economy of the modern industry and society overall, Meadows et al. insisted that the economic analysis of growth centered on the negative impacts on society and the environment [1]. Innovations sometimes turn out to cause severe negative externalities after they have successfully passed the market test. In such cases, the social costs that are revealed only later may result in substantial losses [2]. These costs include serious social problems such as irresponsible resource development, explosive mass production, distribution and logistics that generate huge carbon emissions, serious environmental problems, an extreme poverty gap, unemployment, and population problems.

This has affected the supply and demand of the resources and manpower that is needed by the enterprises, which form the main axis of the economy; eventually, these costs have become a barrier to the formation of the linear circulation structure [3]. This is not merely an internal problem of the company, but rather an awareness of the various social problems that emerge as a consequence of 
rapid growth. Cutting edge technologies such as artificial intelligence and robots can increase the productivity of corporations, but they also expect that social issues such as ethical issues, privacy infringement and information leakage, job loss, and isolation will increase. According to this change, many researchers and practitioners are paying attention to innovative activities and services that are motivated by the goal of meeting a social need [4].

Corporates have started to actively reflect CSR (Corporate Social Responsibility) activities in management as a matter of concern about the social responsibility of corporation. This is evolving into the concept of CSV (creating shared value), which is more actively involved in social and environmental issues and aims to achieve innovation. Porter and Kramer [5] insisted that it is possible to overcome the limitations of corporate growth and achieve continuous innovation by creating shared value beyond corporate social responsibility.

The concept of CSV involves investing to solve social and environmental problems while ensuring sustainable competitiveness of the company and creating a balance between economic and social value [6]. CSV focuses on identifying and expanding the connections between societal and economic progress [7]. The prior studies on CSV mainly focused on social entrepreneurship [8], social capital [9], and value assessment [10].

However, although CSV's main characteristic is to connect between economic value and social value through innovative products and services, the personal value of CVS has not yet been uncovered. Due to the traditional divide between economic concerns and social ones, people in the public and private sectors have often followed very different educational and career paths [11]. This study suggests that personal values have an effect on coordinating and complementing economic and social values that conflict with each other [12]. To address the gap, the purpose of this study is to reveal the effect of personal value as a part of CSV.

Figure 1 shows that CSV consists of business, social, and personal values.

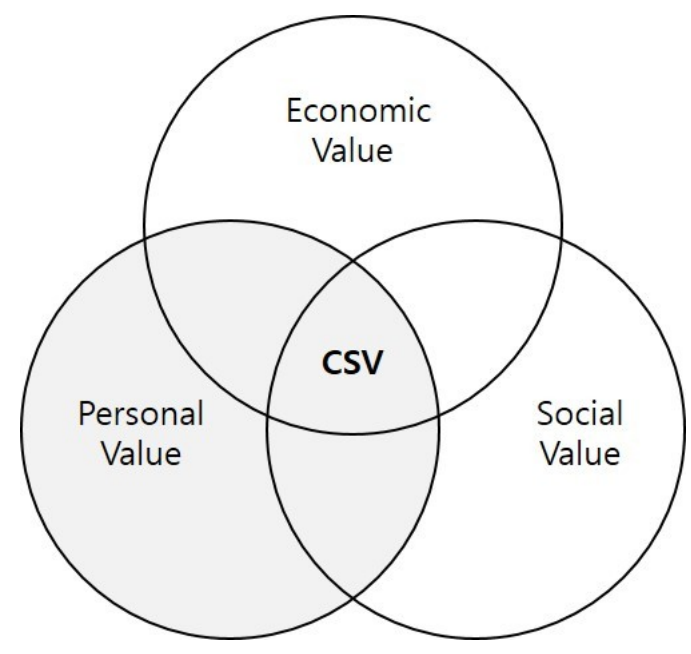

Figure 1. Areas of Personal Value in Creating Shared Value (CSV).

CSV represents a new approach to managing that bridge across disciplines. Specifically, this study addresses the following questions: does self-actualization, as one of the personal value factors, affect CSV? Does goal setting, which is a common factor between personal and economic value, affect CSV? Does solidarity, which is a common factor between personal and social value, affect CSV? To do so, we verify the value of CSV and identify factors of personal value by using an affinity diagram, which categorizes and organizes extracted words in the literature review. Then, we examine the effects of personal value on CSV by surveying 557 university students. The reason for selecting university students is to utilize CSV as a guide in the educational policy of universities that cultivate the future talents of corporates that are making innovation decisions. This research enables setting the direction of education by setting the index of the attitude to increase the value of the individual in the CSV. 


\section{Review of Literature}

\subsection{Concept of CSV (Creating Shared Value)}

Porter and Kramer referred to the need for business and social integration in Strategy and Society [6]: as social standards change and science progresses, both the impact of corporate activities on society and the impact of external social conditions on corporate activities are changing. Thus, enterprises must survive on the basis of a careful process, or frame, to understand the evolution of future societies. At present, the social agendas of enterprises are moving from mitigating damage to strengthening strategies toward social progress. Companies must find a link between social issues and their businesses and have the opportunity to utilize resources and generate profits for society at the same time. Regarding the creation of shared value [11], Porter and Kramer explained the crisis that is occurring in the existing capitalist system and revealed the unified background of economic growth and social progress: in recent years, corporate activities have been perceived as a major cause of social and environmental problems, so public criticism of business activities is growing, and the government's trust is falling. As the government seeks to adjust this problem through regulation (a policy that undermines economic growth), companies need innovation in order to respond.

Porter and Kramer argued that CSV (creating shared value) is a transitional means and an idea that a company in crisis can adopt to move toward new capitalism. It describes the concepts and strengths of CSV as follows: CSV is a corporate activity that creates economic value while solving the challenges facing society to meet its needs and create value. CSV is a corporate activity that focuses on the link between economic growth and social progress, and approaches more expanded capitalism. CSV is a core strategy, not a company's peripheral activities. Based on this concept, Porter and Kramer revealed that CSV would be a power in the future that could create a new wave of global growth, especially related to raising social goals to the same level as corporate strategies.

\subsection{CSV and Personal Value}

CSV has become a major topic of discussion in recent years, as many researchers and practitioners have noted innovative activities that motivate them to achieve goals through meeting their social needs [4]. Among these, many scholars have questioned the concept, logic, and applicability of CSV [13]. In particular, they pointed out that CSV has failed to present a concrete approach or frame to conflicting interests or values, etc. Crane et al. [14] pointed out that CSV ignores the tension between social and economic goals, and overlooks the problem of conflicting social and economic values and stakeholder values. Social and environmental problems that require corporate decision making do not easily reveal clues that can be judged by potential win-win opportunities, but rather cause various stakeholders to clash over ethical views, identities, interests, and values. Pinkhasov [12] also noted that the CSV model presented by Porter and Kramer suggested that the interests of business and social interests overlap, but this excludes the tendency of two values to push each other away. Some scholars are approaching these points based on the stakeholder theory. Rendal [15] stated that in order for a business to be successful, it must be able to create value for all of its external stakeholders, including the entity's owners, investors, leaders, practitioners, customers, and so on, and CSV is no exception. Choi et al. [16] stressed that CSV is a system in which stakeholders work together to create shared values, while some others have stated that CSV allows stakeholders to create new values so that businesses and societies can grow simultaneously. They argued that CSV needs to be approached from a stakeholder perspective, not just from a corporate and social perspective, and that CSV should be able to create value for both the company and its external stakeholders. Pinkhasov [12] proposed personal value as a way to adjust and complement conflicting values within CSV. The author explains that individuals are the key to adjusting the tension that exists between economic value and social value. Companies and communities are collections of individuals, and individuals cross between them as individual components. Tension occurs when the same individual crossing both sides is placed in different positions, roles, and interests, acts on different goals, or is being pressured to do 
so. In this respect, personal value can be a specific approach to conflicting interests and values that CSV overlooks.

\subsection{Factors of Personal Value}

Through the literature review, the factors that make up personal value are defined, and the background is described based in Figure 2.

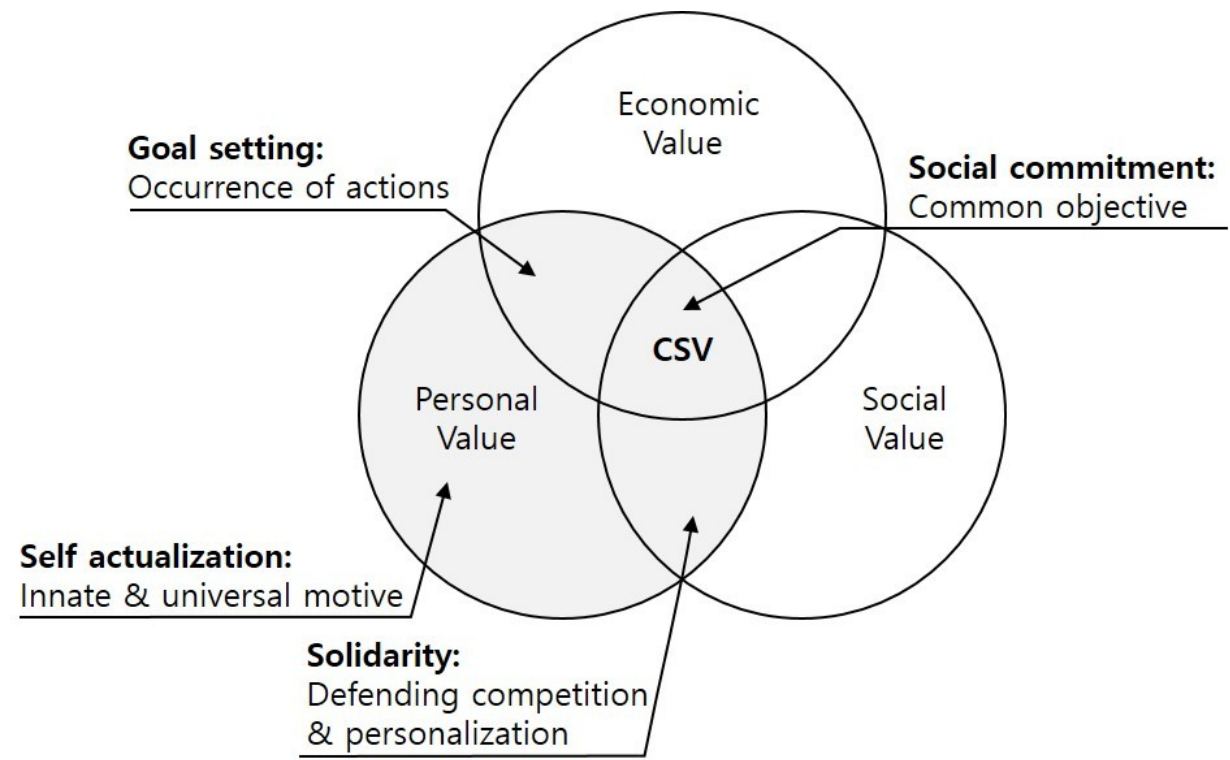

Figure 2. Factors of Personal Value.

Creating Shared Value: CSV is the point at which individual, economic, and social values intersect and are considered common objectives. The existence of an organization, or justification for its activities, arises from a particular objective, and Garard and Cowarsch [17] strongly emphasized that managing the distributed objective in the business or activity involves (or should involve) different entities. Some scholars have pointed out that CSV is approached solely as a corporate objective. As to why tension or the tendency of social and economic values to push each other between social objectives and economic objectives, Vaara and Durand [18] stated that when an enterprise makes a decision, it is because it does not fully review a wide range of social issues, and Barley and Ko [19] said that it only reviews social issues from a corporate interest perspective. To overcome the limitations of this biased approach, CSV needs to be interpreted as common objectives of personal, economic, and social value. Buil et al. [20] noted that in a business based on social issues, stakeholders tend to consider social aspects more than individual interests, which produce positive externalities. This explains the background of the period change in which both consumers and workers value mutual commitments rather than profits. However, Heery and Noon [21] argued that there are limits of integration, saying that it is unrealistic to expect a commitment to integrate because it occurs simultaneously alongside a variety of objects. This study considers that the concept of integrating stakeholder commitment is social commitment, and defines the proxy of CSV as social commitment. In other words, social commitment becomes the common objective of personal, economic, and social value.

Self-actualization: Self-actualization is a component of personal value that was first conceptualized by Maslow and is considered to be a factor affecting CSV in terms of individual universal motivation [22]. Self-actualization refers to the process through which each individual develops their ability, talent, and hidden potential. People are guided in different directions [23] because the motivation for self-actualization is different for each individual. Maslow viewed human motives as based in innate and universal predispositions, and Kenrick et al. [24] noted that Maslow's basic motivations interact with immediate changing external situations, threats, and opportunities, so it needs to be noted for 
its association. In this context, self-actualization can be seen as a factor affecting CSV in terms of universal motivation.

Goal setting: Goal setting is a component of personal value that intersects with economic value and is considered to be a factor that affects CSV in terms of the occurrence of actions. Goal setting is a concept that is similar to the purpose or intention that an individual seeks to achieve. The goal influences performance by concentrating individual attention, mobilizing effort, increasing sustainability, and motivating strategic development. The idea requires visualizing what the desired end is in order to create an action to achieve it [25]. This concept is based on the goal-setting theory, and is in line with the philosophy of Aristotle [26]. Locke (1981) stated that an individual's voluntary and leading intervention in goal setting plays an important role in order to make a significant difference in performance according to goal setting. In this context, goal setting can be seen as an influence on CSV in terms of the occurrence of actions.

Solidarity: Solidarity is a component of personal value that intersects with social value and is considered to affect CSV in terms of defending competition and personalization based on relationships and solidarity. The meaning of solidarity derives from 'the obligation of Roman law'. Solidarity has the characteristics of imposing mutual normative obligations and forming attachment on the basis of a common foundation existing among different individuals. Individuals form a non-compulsory sense of belonging through solidarity, which defends the competition that may arise between individuals, and justifies that attitude [27]. As individualization tends to be perceived as an obstacle to the achievement of the goals of the community, interest in solidarity is growing [28]. The terms "community spirit", "mutual attachment", and "social cooperation" are used as complementary concepts to "solidarity" [27]. In this context, solidarity can be seen as an influence on CSV in terms of relationships and association. Based on the importance of personal value found through our literature review, the elements of CSV and personal value affecting CSV are summarized, as shown in Table 1. Based on this, the variables in this study were defined.

Table 1. Factors of CSV and Personal Value.

\begin{tabular}{|c|c|c|c|c|}
\hline & & ctors & Definition & Reference \\
\hline \multirow[t]{2}{*}{ CSV } & \multirow[t]{2}{*}{$\begin{array}{c}\text { Social } \\
\text { Commitment }\end{array}$} & $\begin{array}{c}\text { social } \\
\text { engagement }\end{array}$ & $\begin{array}{l}\text { degree of awareness of the } \\
\text { connection between oneself, the } \\
\text { community, and society }\end{array}$ & $\begin{array}{c}\text { Berry [29], } \\
\text { Buil et al. [20], } \\
\text { Sabitzer et al. [30], } \\
\text { Hajduk and Zaborek (2016) [31] }\end{array}$ \\
\hline & & ethics & $\begin{array}{l}\text { degree of awareness of the } \\
\text { importance of community norms }\end{array}$ & $\begin{array}{c}\text { Dreyer et al. [32], } \\
\text { Carmenado et al. [33] }\end{array}$ \\
\hline \multirow{8}{*}{ Personal Value } & \multirow{4}{*}{$\begin{array}{l}\text { Self- } \\
\text { actualization }\end{array}$} & self-consciousness & $\begin{array}{c}\text { degree of sensitivity to change } \\
\text { and judgment }\end{array}$ & $\begin{array}{l}\text { Smith [34], } \\
\text { Crone [35], } \\
\text { Buil et al. [20] }\end{array}$ \\
\hline & & self-confidence & $\begin{array}{l}\text { degree of trust in oneself to } \\
\text { do things }\end{array}$ & $\begin{array}{l}\text { Hameed et al. [36] } \\
\text { Bénabou and Tirole [37] }\end{array}$ \\
\hline & & creativity & $\begin{array}{l}\text { degree of novelty or difference in } \\
\text { the way in which oneself views a } \\
\text { phenomenon or problem }\end{array}$ & $\begin{array}{l}\text { McLeod et al. [38], } \\
\text { Buil et al. [20], } \\
\text { Carmenado et al. [33] }\end{array}$ \\
\hline & & challenge & $\begin{array}{l}\text { degree to which one is positive or } \\
\text { active in one's work }\end{array}$ & Zhou [39] \\
\hline & \multirow{4}{*}{ Goal setting } & common objectives & $\begin{array}{l}\text { degree to which one values } \\
\text { achieving one's goals }\end{array}$ & $\begin{array}{l}\text { Barrett [40] } \\
\text { Tuncay and Erbay [41] }\end{array}$ \\
\hline & & participation & $\begin{array}{l}\text { degree to which one intends to } \\
\text { influence the } \\
\text { decision-making process }\end{array}$ & $\begin{array}{l}\text { Marin et al. [42] } \\
\text { Burns et al. [43] }\end{array}$ \\
\hline & & leadership & $\begin{array}{l}\text { degree to which one seeks to } \\
\text { lead others }\end{array}$ & $\begin{array}{c}\text { Locke [26], } \\
\text { Dreyer et al. [32], } \\
\text { Carmenado et al. [33] }\end{array}$ \\
\hline & & tolerance & $\begin{array}{l}\text { the degree to which uncertainty is } \\
\text { endured; to accept the thoughts } \\
\text { of others }\end{array}$ & $\begin{array}{l}\text { Cerqueti et al. [44] } \\
\text { Bjørnskov [45] } \\
\text { Zhou [39] }\end{array}$ \\
\hline
\end{tabular}


Table 1. Cont.

\begin{tabular}{lcccc}
\hline & Factors & Definition & Reference \\
\hline & Solidarity & relationship & $\begin{array}{c}\text { degree to which one tries to } \\
\text { interact with others, with } \\
\text { communities }\end{array}$ & Johansen and Nielsen [46] \\
\cline { 2 - 5 } Personal Value & cooperation & $\begin{array}{c}\text { degree of agreement and } \\
\text { coordination within a community }\end{array}$ & $\begin{array}{c}\text { Lu et al. [47], } \\
\text { Kwon and Woo [48], } \\
\text { Pysz [49] }\end{array}$ \\
\cline { 2 - 6 } & communication & $\begin{array}{c}\text { degree of semantic transmission } \\
\text { to others and communities }\end{array}$ & Carmenado et al. [33] \\
\hline
\end{tabular}

\section{Hypotheses and Research Design}

This study has three research hypotheses to determine whether self-actualization, goal setting, and solidarity, which make up the personal value of CSV, have a positive effect on CSV:

Hypothesis 1: Self-actualization will have an effect on CSV.

Hypothesis 2: Goal setting will have an effect on CSV.

Hypothesis 3: Solidarity will have an effect on CSV.

This paper applied the regression model to test the hypotheses. Figure 3 presents the study model.

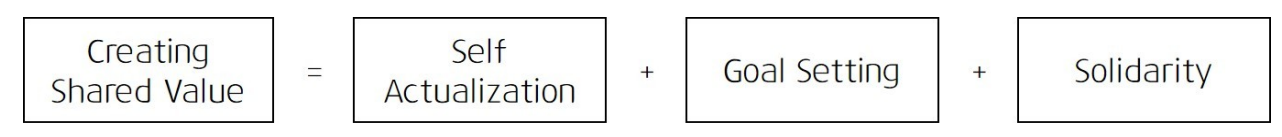

Figure 3. Study Model.

Creating Shared Value: CSV is the point at which personal, economic, and social values intersect and are considered a common objective of all of them. The proxy of CSV is social commitment, and the factors that make up social commitment are social engagement and ethics.

Self-actualization: Self-actualization is a component of personal value and is considered to be a factor affecting CSV in terms of individual universal motivation. The factors that make up self-actualization are self-consciousness, self-confidence, creativity, and challenge.

Goal-setting: Goal setting is a component of personal value intersecting with economic value and is considered to be a factor affecting CSV in terms of the basis for action occurrence. The factors that make up goal setting are common objectives, participation, leadership, and tolerance.

Solidarity: Solidarity is a component of personal value that intersects with social value and is considered to affect CSV in terms of defending competition or personalization based on relationships and solidarity. The factors that make up solidarity are relationship, cooperation, and communication.

\section{Samples}

In this study, survey questionnaires are designed to collect data on the main factors of personal value and CSV. The questionnaire used in the survey was attached to the Appendix A. Most students haven't focused on social values, and a few students took the related social and ethics courses because all the majors in K University are related to engineering except for business administration. CSV activities for students have been conducted actively since 2018. Thus, the samples for the paper were collected from a student survey at K University in the fall of 2018. The K University is based on engineering, and located in Korea. A total of 553 randomly selected university undergraduate students completed responses out of a total of 557, of which four were graduate students. Thus, we used a total of 557 samples. Table 1 presents the distribution of 557 samples. Of the 557 respondents, $65.35 \%$ were male and $34.65 \%$ were female. In Table 2, regarding college year distribution, the portion of freshmen, 
sophomores, juniors, and senior were respectively $23.16 \%, 20.11 \%, 33.21 \%$, and $22.8 \%$, implying a college year balance for the sample. Looking at major distribution, $29.08 \%$ were studying business and industrial engineering, $24.06 \%$ were studying electronics and mechanical engineering, $15.8 \%$ were studying chemical and materials, $10.23 \%$ were studying computer and information technology (IT), and $20.83 \%$ were studying other subjects. Regarding grade point average (GPA), $42.54 \%$ of the students had a higher than 3.0 GPA out of a total of 4.5, which was the largest group in the sample. The portion of students who had a GPA higher than 4.0 was $4.13 \%$, which was the lowest group in the sample.

Table 2. Sample Distribution (N = 557). GPA: grade point average, IT: information technology.

\begin{tabular}{|c|c|c|c|}
\hline & Characteristics & Frequency & Percentage (\%) \\
\hline \multirow{2}{*}{ Gender } & Male & 364 & 65.35 \\
\hline & Female & 193 & 34.65 \\
\hline \multirow{5}{*}{ College Year } & Freshmen & 129 & 23.16 \\
\hline & Sophomore & 112 & 20.11 \\
\hline & Junior & 185 & 33.21 \\
\hline & Senior & 127 & 22.8 \\
\hline & Graduate school & 4 & 0.72 \\
\hline \multirow{5}{*}{ Major } & $\begin{array}{l}\text { Business/Industrial } \\
\text { engineering }\end{array}$ & 162 & 29.08 \\
\hline & Computer/IT & 57 & 10.23 \\
\hline & Electronic/Mechanical & 134 & 24.06 \\
\hline & Chemical/Materials & 88 & 15.80 \\
\hline & Others & 116 & 20.83 \\
\hline \multirow{5}{*}{$\begin{array}{l}\text { GPA } \\
(4.5)\end{array}$} & 4.0 or over & 23 & 4.13 \\
\hline & 3.5 or over & 73 & 13.11 \\
\hline & 3.0 or over & 237 & 42.54 \\
\hline & 2.5 or over & 173 & 31.10 \\
\hline & 2.0 or over & 51 & 9.12 \\
\hline
\end{tabular}

\section{Empirical Results}

\subsection{Descriptive Statistics}

A confirmative factor analysis was used to show the construct validity of the variables based on survey questions. This paper used confirmative factor analysis provided in the literature by dividing questions into four groups based on prior studies: social commitment, self-actualization, goal-setting, and solidarity. The varimax rotation of the confirmative factor analysis generated 12 variables: social engagement, ethics, self-consciousness, self-confidence, creativity, challenge, common objective, participation, leadership, tolerance, relationship, and cooperation. All of these variables were reliable with Cronbach's alpha values greater than 0.9 in Table 3. This means that the average scores of the questions that make up the 12 variables can be used for empirical tests.

Table 3 shows the descriptive statistics of the variables based on the five-point Likert scale scores of related questions. We obtained the response means for each individual question contained in each factor, and then the average and standard deviation. The means of social commitment were 3.314 and 3.945. In self-actualization, the mean was around 3.8 except for creativity, which has a mean around 3.5. In goal setting, the means ranged from 3.943 to 3.549 . The mean of relationship was 3.311, showing the lowest among all the variables. 
Table 3. Descriptive Statistics and Cronbach's Alpha.

\begin{tabular}{ccccc}
\hline & $\begin{array}{c}\text { Number of } \\
\text { Questions }\end{array}$ & Mean & Std. & Cronbach's \\
\hline $\begin{array}{c}\text { < Social } \\
\text { Commitment }>\end{array}$ & 8 & 7.259 & 1.116 & 0.918 \\
Social Engagement & 5 & 3.314 & 0.737 & 0.923 \\
\hline Ethics & 3 & 3.945 & 0.600 & 0.921 \\
\hline <Self-Actualization $>$ & 13 & 15.064 & 2.099 & 0.915 \\
Self-Consciousness & 3 & 3.947 & 0.606 & 0.925 \\
\hline Self-Confidence & 4 & 3.725 & 0.712 & 0.918 \\
\hline Creativity & 3 & 3.518 & 0.670 & 0.921 \\
\hline Challenge & 3 & 3.872 & 0.819 & 0.921 \\
\hline <Goal-Setting $>$ & 13 & 14.721 & 2.118 & 0.914 \\
Common Objective & 3 & 3.943 & 0.587 & 0.92 \\
\hline Participation & 3 & 3.649 & 0.746 & 0.921 \\
\hline Leadership & 5 & 3.549 & 0.686 & 0.918 \\
\hline Tolerance & 2 & 3.581 & 0.996 & 0.927 \\
\hline$<$ Solidarity $>$ & 7 & 7.305 & 1.110 & 0.915 \\
\hline Relationship & 3 & 3.311 & 0.772 & 0.921 \\
\hline Cooperation & 4 & 3.991 & 0.581 & 0.918 \\
\hline
\end{tabular}

\subsection{Main Results}

In this study, we analyzed the effect of personal value on CSV. We used social engagement and ethics for the proxies of CSV (creating shared value) and self-actualization, goal-setting, and solidarity are used for the proxies of personal value. Table 4 shows the results of regressing the effect of self-actualization on CSV. In Panel A of Table 4, the dependent variable is social engagement, which is a proxy for CSV, and the independent variables are self-consciousness, self-confidence, creativity, and challenge, which are proxies for self-actualization. In Panel A of Table 4, the coefficient of self-consciousness is insignificant and the estimated value of self-confidence is 0.226557 ( $t$-statistic $=3.47$ ), which was significantly less than one ( $p$-value $=0.001$ ), and means that social engagement increases as self-confidence goes up. The coefficients of creativity and challenge are positive and significant (coefficient $=0.29472$, t-statistic $=3.38$, coefficient $=0.1394$, t-statistic $=2.07$ ), respectively. It implies that high creativity and challenge lead to more social engagement. Looking at the control variables, the coefficient of college year is 0.36586 ( $\mathrm{t}$-statistic $=2.74$ ) and significant. It means that college students who are closer to graduating are more socially engaged. GPA and major variables don't affect CSV.

In Panel B of Table 4, the dependent variable is ethics, which is another proxy for CSV. In Panel B of Table 4, the coefficients of self-consciousness, self-confidence, and challenge are significantly positive at the $1 \%$ level. This indicates that ethics have a positive relationship with self-actualization. When self-consciousness and self-confidence increase, ethics improve, and when we are more challenged, ethics strengthen.

These results prove that self-actualization affects creating shared value positively, supporting the first hypothesis.

Table 5 presents the relationship between goal setting and social commitment. In Panel A of Table 5, the coefficient of common objective is positive and significant (coefficient $=0.42714$, $\mathrm{t}$-statistic $=4.58$ ), and coefficient of participation is also positive and significant (coefficient $=0.14588$, t-statistic $=1.81$ ). The coefficients of leadership and tolerance are significant and positive (coefficient $=0.11624$, t-statistic $=2.21$; coefficient $=0.2087$, t-statistic $=2.79$, respectively) . 
Table 4. Effects of Self-Actualization on Creating Shared Value (CSV).

\begin{tabular}{|c|c|c|c|c|}
\hline & \multicolumn{2}{|c|}{$\begin{array}{l}\quad<\text { Panel } \mathrm{A}> \\
\text { Social Engagement }\end{array}$} & \multicolumn{2}{|c|}{$\begin{array}{c}<\text { Panel B }> \\
\text { Ethics }\end{array}$} \\
\hline & Coeff. & t-stat & Coeff. & t-stat \\
\hline Intercept & $3.93621^{* * *}$ & 2.83 & $4.49092^{* * *}$ & 7.13 \\
\hline Self-Consciousness & 0.07667 & 0.84 & $0.16365^{* * *}$ & 3.95 \\
\hline Self-Confidence & $0.22655^{* * *}$ & 3.47 & $0.14452^{* * *}$ & 4.89 \\
\hline Creativity & $0.29472^{* * *}$ & 3.38 & 0.0562 & 1.42 \\
\hline Challenge & $0.1394^{* *}$ & 2.07 & $0.16068^{* * *}$ & 5.27 \\
\hline College Year & $0.36586^{* * *}$ & 2.74 & $0.1492^{* *}$ & 2.47 \\
\hline Major & -0.0025 & -0.03 & -0.0328 & -0.73 \\
\hline Gender & $1.59169^{* * *}$ & 5.19 & 0.06604 & 0.48 \\
\hline GPA & 0.1628 & 1.06 & $0.12786^{*}$ & 1.83 \\
\hline Adj. R2 & \multicolumn{2}{|c|}{$16.27 \%$} & \multicolumn{2}{|c|}{$28.05 \%$} \\
\hline
\end{tabular}

In Panel B of Table 5, most of the variables are significant except for tolerance, which is similar to the results of Panel A of Table 5. These results suggest that goal setting affects social commitment positively, supporting the second hypothesis.

Table 5. Effects of Goal Setting on CSV.

\begin{tabular}{|c|c|c|c|c|}
\hline & \multicolumn{2}{|c|}{$\begin{array}{c}\quad<\text { Panel A }> \\
\text { Social Engagement }\end{array}$} & \multicolumn{2}{|c|}{$\begin{array}{c}<\text { Panel B }> \\
\text { Ethics }\end{array}$} \\
\hline & Coeff. & t-stat & Coeff. & t-stat \\
\hline Intercept & $3.34499^{* * * *}$ & 2.54 & $4.74408^{* * *}$ & 7.84 \\
\hline Common Objective & $0.42714^{* * *}$ & 4.58 & $0.30884^{* * *}$ & 7.19 \\
\hline Participation & $0.14588^{*}$ & 1.81 & $0.14106^{* * *}$ & 3.81 \\
\hline Leadership & $0.11624^{* *}$ & 2.21 & $0.06093^{* * *}$ & 2.52 \\
\hline Tolerance & $0.2087^{* * *}$ & 2.79 & 0.05265 & 1.53 \\
\hline College Year & $0.25203^{*}$ & 1.88 & 0.08389 & 1.36 \\
\hline Major & 0.01137 & 0.12 & -0.05442 & -1.2 \\
\hline Gender & $1.40792^{* * *}$ & 4.65 & -0.02654 & -0.19 \\
\hline GPA & 0.12894 & 0.84 & $0.12645^{*}$ & 1.78 \\
\hline Adj. R2 & \multicolumn{2}{|c|}{$16.44 \%$} & \multicolumn{2}{|c|}{$26.01 \%$} \\
\hline
\end{tabular}

Table 6 provides the results of the third hypothesis: solidarity has a positive association with CSV. In Table 6, all the proxies for solidarity are significantly positive at the $1 \%$ level. In Panel A of Table 5, the coefficients of relationship and cooperation are $0.46336(\mathrm{t}$-statistic $=7.33)$ and 0.40249 (t-statistic $=6.38)$, respectively. In Panel B of Table 6, the coefficients of relationship and cooperation are 0.08397 (t-statistic $=2.72$ ) and $0.33248(\mathrm{t}$-statistic $=10.8)$, respectively. It means that more solidarity increases social engagement and ethics. 
Table 6. Effects of Solidarity on CSV.

\begin{tabular}{|c|c|c|c|c|}
\hline & \multicolumn{2}{|c|}{$\begin{array}{c}\quad<\text { Panel A }> \\
\text { Social Engagement }\end{array}$} & \multicolumn{2}{|c|}{$\begin{array}{c}<\text { Panel } B> \\
\text { Ethics }\end{array}$} \\
\hline & Coeff. & t-stat & Coeff. & t-stat \\
\hline Intercept & 2.14595 & 1.76 & 5.06757 & 8.5 \\
\hline Relationship & $0.46336^{* * *}$ & 7.33 & $0.08397^{* * *}$ & 2.72 \\
\hline Cooperation & $0.40249^{* * *}$ & 6.38 & $0.33248^{* * *}$ & 10.8 \\
\hline College Year & $0.3122^{* *}$ & 2.48 & $0.11855^{*}$ & 1.93 \\
\hline Major & 0.06339 & 0.68 & -0.03548 & -0.78 \\
\hline Gender & $1.21857^{* * *}$ & 4.24 & -0.1449 & -1.03 \\
\hline GPA & 0.22834 & 1.57 & $0.18663^{* * *}$ & 2.63 \\
\hline Adj. R2 & \multicolumn{2}{|c|}{$23.59 \%$} & \multicolumn{2}{|c|}{$24.65 \%$} \\
\hline
\end{tabular}

Table 7 reports the effects of personal values included all the variables-self-actualization, goal setting, and solidarity-on CSV. Looking at Panel A of Table 7, the variables of a common objective, relationship, and cooperation are significant and positive. However, the coefficient of leadership is significantly negative (coefficient $=-0.14633$, t-statistic $=-2.46$ ), showing the opposite expected result. This result indicates that greater leadership leads to lower social engagement when we consider personal values at the same time. It suggests that our society will require servant leaders instead of charismatic leaders to improve CSV. In Panel of Table 7, the qualities of self-consciousness, self-confidence, and challenge among the self-actualization variables are significant and positive (coefficient $=0.14448$, $\mathrm{t}$-statistic $=3.46 ;$ coefficient $=0.07133, \mathrm{t}$-statistic $=2.28$, coefficient $=0.08319$, $\mathrm{t}$-statistic $=2.64$ ). It implies that ethics are higher when we are more self-conscious, have more self-confidence, and encounter greater challenges. Seeing the effects of goal setting on ethics, the coefficient of a common objective is 0.13186 ( $\mathrm{t}$-statistic $=2.84$ ), and the coefficient of participation is significant at 0.11715 ( $\mathrm{t}$-statistic $=3.14$ ). This result suggests that ethics would be improved as we have common goals and actively participate in organizations. Finally, from the solidarity perspective, the coefficient of cooperation is significant 0.14446 ( $t$-statistic $=3.95$ ), showing that greater cooperation leads to higher ethics. These results are similar to the results of those of Table 4, Table 5, and Table 6.

Table 7. Effects of Personal Values on CSV 1.

\begin{tabular}{ccccc}
\hline & \multicolumn{2}{c}{ Social Engagement } & \multicolumn{2}{c}{ E Panel B> } \\
& Coeff. & t-stat & Coeff. & t-stat \\
\cline { 2 - 5 } & -0.11096 & -0.08 & 2.53645 & 3.81 \\
\hline Intercept & 0.071 & 0.78 & $0.14448^{* * *}$ & 3.46 \\
\hline Self-Consciousness & 0.05887 & 0.87 & $0.07133^{* *}$ & 2.28 \\
\hline Self-Confidence & 0.13179 & 1.48 & 0.0036 & 0.09 \\
\hline Creativity & 0.00341 & 0.05 & $0.08319^{* * *}$ & 2.64 \\
\hline Challenge & $0.2376^{* *}$ & 2.35 & $0.13186^{* * *}$ & 2.84 \\
\hline Common Objective & -0.00585 & -0.07 & $0.11715^{* * *}$ & 3.14 \\
\hline Participation & $-0.14633^{* *}$ & -2.46 & -0.0146 & -0.53 \\
\hline Leadership & 0.09129 & 1.27 & 0.0207 & 0.62 \\
\hline Tolerance & $0.46612^{* * *}$ & 6.18 & -0.01075 & -0.31 \\
\hline Relationship & $0.29445^{* * *}$ & 3.71 & $0.14446^{* * *}$ & 3.95 \\
\hline Cooperation & & & &
\end{tabular}


Table 7. Cont.

\begin{tabular}{|c|c|c|c|c|}
\hline & \multicolumn{2}{|c|}{$\begin{array}{c}\quad<\text { Panel A }> \\
\text { Social Engagement }\end{array}$} & \multicolumn{2}{|c|}{$\begin{array}{c}<\text { Panel B }> \\
\text { Ethics }\end{array}$} \\
\hline & Coeff. & t-stat & Coeff. & t-stat \\
\hline College Year & $0.29183^{* *}$ & 2.29 & $0.10648^{*}$ & 1.81 \\
\hline Major & 0.079 & 0.83 & -0.01859 & -0.43 \\
\hline Gender & $1.3377^{* * *}$ & 4.57 & 0.01359 & 0.1 \\
\hline GPA & 0.17971 & 1.22 & 0.10655 & 1.57 \\
\hline Adj. R2 & \multicolumn{2}{|c|}{$25.22 \%$} & \multicolumn{2}{|c|}{$34.28 \%$} \\
\hline
\end{tabular}

In Table 8 , self-actualization is the sum of self-consciousness, self-confidence, creativity, and challenge. Goal setting is the sum of a common objective, participation, leadership, and tolerance. Solidarity is the sum of cooperation and relationship, and social commitment leading to CSV is the sum of social engagement and ethics. In Table 8, all the independent variables-self-actualization, goal setting, and solidarity_have a relationship with CSV, supporting all the hypotheses.

Table 8. Effects of the Personal Values on CSV 2.

\begin{tabular}{|c|c|c|}
\hline & \multicolumn{2}{|c|}{ Social Commitment } \\
\hline & Coeff. & t-stat \\
\hline Intercept & $1.29506^{* * *}$ & 3.51 \\
\hline Self-Actualization & $0.13645^{* * *}$ & 5.47 \\
\hline Goal-Setting & $0.05802^{* *}$ & 2.19 \\
\hline Solidarity & $0.28774^{* * *}$ & 5.75 \\
\hline College Year & $0.11199^{* * *}$ & 3.17 \\
\hline Major & -0.0035 & -0.13 \\
\hline Gender & $0.27813^{* * *}$ & 3.43 \\
\hline GPA & $0.09005^{* *}$ & 2.21 \\
\hline Adj. R2 & \multicolumn{2}{|c|}{$36.10 \%$} \\
\hline
\end{tabular}

\section{Conclusions}

This study examines the main factors of the personal values that influence on CSV. The empirical results are as follows. First, social engagement has a relationship with self-confidence, creativity, and challenge. Ethics would be improved as we have more self-consciousness, more self-confidence, and more challenges. This means that CSV increases when we are more self-actualized.

Second, social engagement was affected by goal-setting variables such as having a common objective, participation, leadership, and tolerance. Ethics were associated with having a common objective, participation, and leadership. These results suggest that goal setting affects CSV.

Third, from the solidarity perspective, social engagement and ethics would be increased by relationships and cooperation. It implies that CSV goes up as we have many relationships with organizations and are more cooperative in work.

Our society pays a disproportionate amount of attention to economics, even though we belong to the university. The prevailing theories in many of the management disciplines have broken down as a result of environmental changes. Neither schools nor curricula have adapted [50]. This study is meaningful. First, we suggest the important elements of personal values for CSV at university. 
Second, this research enables setting the direction of the education by setting the index of the attitude to increase the value of the individual in CSV. With an emphasis on the importance of using knowledge to solve common problems facing society [51], the importance of education to the social impact of business activities [52], and so on, this study lays the foundation for access to education for CSV. The study found three personal values that make up CSV, and defined each as follows. Self-actualization is the universal motivation of the individual, goal setting is the basis for action occurrence, and solidarity is the relationship factor that defends competition and personalization. These findings and definitions will be used in a meaningful way to build a balanced educational framework that considers social values in the future.

Before we designed this study, we anticipated that students with leadership skills would be less cooperative. It was impressive that the results were not different from what we anticipated. This can be interpreted as a result of the tendency of the social and educational environment of leadership to exclude social commitment. It is necessary to establish a social and educational environment to cultivate entrepreneurship that has a new approach to leadership — that is, an inclusive attitude-in order to cope with changes that emphasize social values.

In the future, we plan to conduct a CSV-based experiment project reflecting the findings derived from this study, and to conduct a study to compare the differences between the students who participated in the project and those who did not.

Author Contributions: Conceptualization, S.K.; Investigation, J.K.; Methodology, J.K.; Project administration, S.K.; Writing-original draft, S.B.

Funding: Not applicable. No funding was received.

Acknowledgments: This research was supported by the MSIT (Ministry of Science, ICT), Korea, under the ITRC (Information Technology Research Center) support program (IITP-2019-2014-1-00639) supervised by the IITP (Institute for Information \& communications Technology Planning \& Evaluation).

Conflicts of Interest: The authors declare no conflict of interest.

\section{Appendix A}

\begin{tabular}{lc}
\hline 1 & I am connected with the community. \\
\hline 2 & The community helps me. \\
\hline 3 & I am a part of the community. \\
\hline 5 & People in the community are influenced by each other. \\
\hline 6 & I feel like a member of the community. \\
\hline 7 & I understand and consider the situation of others. \\
\hline 9 & I handle all activities transparently and fairly. \\
\hline 10 & I think that I am worthy of work in the community. \\
\hline 11 & I am pleased with the success of others. \\
\hline 12 & I can distinguish what I want and what I do not want. \\
\hline 13 & I can distinguish my advantages and disadvantages. \\
\hline 14 & I can notice what is an opportunity. \\
\hline 15 & I can notice what is a crisis. \\
\hline 16 & I can distinguish the benefits and losses to me. \\
\hline 17 & I have faith in my ability or value. \\
\hline
\end{tabular}




\begin{tabular}{|c|c|}
\hline 18 & I act with confidence. \\
\hline 19 & I think I can do anything. \\
\hline 20 & I think I can change the world with my efforts. \\
\hline 21 & I often have different viewpoints from others. \\
\hline 22 & I can find a connection between different things. \\
\hline 23 & I am good at connecting different perspectives and views. \\
\hline 24 & I'm good at coming up with ideas. \\
\hline 25 & When I face a problem, I suggest various alternatives. \\
\hline 26 & I tend to try new things. \\
\hline 27 & I try to make a better situation. \\
\hline 28 & I try to overcome difficulties and limitations. \\
\hline 29 & I encourage myself and the community to work well together. \\
\hline 30 & I find pleasure and meaning in challenging work. \\
\hline 31 & When I work, I value vision and goal setting. \\
\hline 32 & I try to achieve my goals. \\
\hline 33 & The goal should be set in the right direction. \\
\hline 34 & I endure discomfort or sacrifice to achieve my goals. \\
\hline 35 & I enjoy the process of achieving my goals. \\
\hline 36 & I tend to actively participate when I work. \\
\hline 37 & I tend to suggest opinions and ideas when I work. \\
\hline 38 & I tend to spend time on common activities. \\
\hline 39 & I am interested in solving common problems. \\
\hline 40 & I am very active in solving common problems. \\
\hline 41 & I plan what I have to do to achieve my goals. \\
\hline 42 & I can plan what I want to do. \\
\hline 43 & I prioritize what I have to do. \\
\hline 44 & I can create and analyze various alternatives. \\
\hline 45 & I can assign and coordinate the work of the team. \\
\hline 46 & I like to be assigned a position or take on a task. \\
\hline 47 & I present directions to others. \\
\hline 48 & I have an influence on the behavior of others. \\
\hline 49 & I motivate others. \\
\hline 50 & I lead others to achieve common goals. \\
\hline 51 & I tend to put up with difficulties. \\
\hline 52 & I tend to endure an uncertain situation. \\
\hline 53 & I am inclusive of other people's opinions. \\
\hline 54 & I can wait long enough for someone else to make a decision. \\
\hline 55 & I can negotiate and reach consensus. \\
\hline 56 & I prefer to work in connection with external organizations. \\
\hline
\end{tabular}




\begin{tabular}{lc}
\hline 57 & I am connected with various external organizations. \\
\hline 58 & I know what external organizations and stakeholders need. \\
\hline 59 & I have good relationships with others. \\
\hline 60 & I think sustained relationships are important. \\
\hline 61 & I consider the interests of others when collaborating. \\
\hline 62 & I consider various points of view when collaborating. \\
\hline 64 & Even if I disagree, I accept the opinions of others. \\
\hline 65 & I can integrate the opinions of others when collaborating. \\
\hline 67 & I like to cooperate when I work. \\
\hline 68 & I treat others with an open mind. \\
\hline 69 & I express my thoughts and opinions appropriately. \\
\hline 70 & I communicate in consideration of the other's conditions. \\
\hline
\end{tabular}

\section{References}

1. Meadows, D.H.; Meadows, D.L.; Randers, J.; Behrens, W.W., III. The Limits to Growth; Universe Books; Potomac Associates: New York, NY, USA, 1972.

2. Witt, U. What kind of innovations do we need to secure our future? J. Open Innov. Technol. Mark. Complex. 2016, 2, 17. [CrossRef]

3. Delarue, A.; Gryp, S.; Hootegem, G.V. The quest for a balanced manpower capacity: Different flexibility strategies examined. In Enterprise and Work Innovation Studies; Universidade Nova de Lisboa: Lisbon, Portugal, 2006; No. 2.

4. Lim, H.J.; Eun, J.H. Exploring Perceptions of Sustainable Development in South Korea: An Approach Based on Advocacy Coalition Framework's Belief System. J. Open Innov. Technol. Mark. Complex. 2018, 1, 54. [CrossRef]

5. Porter, M.E.; Kramer, M.R. The Competitive Advantage of Corporate Philanthropy. Harv. Bus. Rev. 2002, RO212D, 5-14.

6. Porter, M.E.; Kramer, M.R. Strategy and Society: The Link between Competitive Advantage and Corporate Social Responsibility. Harv. Bus. Rev. 2006, 84, 78-92. [PubMed]

7. Yun, J.H. How do we conquer the growth limits of capitalism? Schumpeterian Dynamics of Open Innovation. J. Open Innov. Technol. Mark. Complex. 2015, 1, 17. [CrossRef]

8. Son, H.S.; Lee, J.S.; Chung, Y.H. Value Creation Mechanism of Social Enterprises in Manufacturing Industry: Empirical Evidence from Korea. Sustainability 2017, 10, 46. [CrossRef]

9. Lin, N. Social Capital: A Theory of Social Structure and Action; Cambridge University Press: Cambridge, UK, 2001.

10. Acquier, A.; Valiorgue, B.; Daudigeos, T. Sharing the Shared Value: A Transaction Cost Perspective on Strategic CSR Policies in Global Value Chains. J. Bus. Ethics 2015, 144, 139-152. [CrossRef]

11. Porter, M.E.; Kramer, M.R. Creating Shared Value. Harv. Bus. Rev. 2011, 89, 62-77.

12. Pinkhasov, M. Creating Shared Value for Individual. Available online: http://www.ver.pt/criar-valorpartilhado-para-os-individuos (accessed on 20 November 2014).

13. Kim, R.C. Can Creating Shared Value (CSV) and the United Nations Sustainable Development Goals (UN SDGs) Collaborate for a Better World? Insights from East Asia. Sustainability 2018, 10, 4128. [CrossRef]

14. Crane, A.; Palazzo, G.; Spence, L.J.; Matten, D. Contesting the Value of Creating Shared Value. Calif. Manag. Rev. 2014, 56, 130-153. [CrossRef]

15. Rendal, J.P. How Creating Shared Value is Taking Corporate Social Responsibility One Step Further. Google as a Case Study; University of Coruna: La Coruña, Spain, 2015. 
16. Choi, D.W.; Kim, K.B.; Lee, S.M. The Impact of Companies Creating Shared Value on Stakeholders; Korean Strategic Management Society: Seoul, Korea, 2013; pp. 2013-2243.

17. Garard, J.; Kowarsch, M. Objectives for Stakeholder Engagement in Global Environmental Assessments. Sustainability 2017, 9, 1571. [CrossRef]

18. Vaara, E.; Durand, R. How to Connect Strategy Research with Broader Issues that Matter. Strateg. Organ. 2012, 10, 248-255. [CrossRef]

19. Barley, S.R.; Ko, M. Corporations, Democracy, and the Public Good. J. Manag. Inq. 2007, 16, $201-215$. [CrossRef]

20. Buil, M.; Aznar, J.P.; Galiana, J.; Marco, A.R. An Explanatory Study of MBA Students with Regards to Sustainability and Ethics Commitment. Sustainability 2016, 8, 280. [CrossRef]

21. Heery, E.; Noon, M. A Dictionary of Human Resource Management; Oxford University Press: Oxford, UK, 2001.

22. Maslow, A. Motivation and Personality; Harper \& Brothers: Manhattan, NY, USA, 1954; ISBN 978-0-06-041987-5.

23. Heylighen, F. A Cognitive Systemic Reconstruction of Maslow's Theory of Self-Actualizaion. Behav. Sci. 1992, 37, 39-58. [CrossRef]

24. Kenrick, D.T.; Griskevicius, V.; Neuberg, S.L.; Schaller, M. Renovating the Pyramid of Needs: Contemporary Extensions Built Upon Ancient Foundations. Perspect. Psychol. Sci. 2010, 5, 292-314. [CrossRef] [PubMed]

25. Locke, E.A. Goal Setting and Task Performance: 1969-1980. Psychol. Bull. 1981, 90, 125. [CrossRef]

26. Locke, E.A. Motivation through Conscious goal setting. Appl. Prev. Psychol. 1996, 5, 117-124. [CrossRef]

27. Bayertz, K. Four Uses of Solidarity. In Solidarity; Philosophical Studies in Contemporary Culture: University of Münster, Münster, Germany, 1999; Volume 5.

28. Crow, G. Social Solidarities: Theories, Identities, and Social Change; Open University Press: Buckingham, UK, 2002.

29. Berry, J.W. Integration and Multiculturalism: Ways towards Social Solidarity. Pap. Social Represent. Peer Rev. Online J. 2011, 20. Available online: http://psr.iscte-iul.pt/index.php/PSR/article/view/414 (accessed on 10 June 2019).

30. Sabitzer, T.; Hartl, B.; Marth, S.; Hofmann, E.; Penz, E. Preventing Conflicts in Sharing Communities as a Means of Promoting Sustainability. Sustainability 2018, 10, 2828. [CrossRef]

31. Hajduk, M.K.W.; Zaborek, P. Does Business Model Affect CSR Involvement? A Survey of Polish Manufacturing and Service Companies. Sustainability 2016, 8, 93. [CrossRef]

32. Dreyer, M.; Chefneux, L.; Goldberg, A.; Von Heimburg, J.; Patrignani, N.; Schofield, M.; Shilling, C. Responsible Innovation: A Complementary View from Industry with Proposals for Bridging Different Perspectives. Sustainability 2017, 9, 1719. [CrossRef]

33. Carmenado, I.D.L.R.; Ortuño, M.; Rivera, M. Private-Public Partnership as a Tool to Promote Entrepreneurship for Sustainable Development: WWP Torrearte Experience. Sustainability 2016, 8, 199. [CrossRef]

34. Smith, J. Self-Consciousness. In Stanford Encyclopedia of Philosophy; Metaphysics Research Lab of Stanford University: Stanford, CA, USA, 2017.

35. Crone, K. Self-Consciousness, Interaction, and Understanding Others. 2013. Available online: https: //consciousnessonline.files.wordpress.com/2013/02/crone-co5.pdf (accessed on 10 June 2019).

36. Hameed, I.; Khan, M.B.; Shahab, A.; Hameed, I.; Qadeer, F. Science, Technology and Innovation through Entrepreneurship Education in the United Arab Emirates (UAE). Sustainability 2016, 8, 1280. [CrossRef]

37. Bénabou, R.; Tirole, J. Self Confidence: Intrapersonal Strategies; Woodrow Wilson School Working Paper; Princeton University: Princeton, NJ, USA, 1999.

38. McLeod, P.L.; Lobel, S.A.; Cox, T.H. Ethnic Diversity and Creativity in Small Groups. Small Group Res. 1996, 27. [CrossRef]

39. Zhou, C. A Study on Creative Climate in Project-Organized Groups (POGs) in China and Implications for Sustainable Pedagogy. Sustainability 2018, 10, 114. [CrossRef]

40. Barrett, J.H. Individual Goals and Organizational Objectives; Library of Congress Catalog Card No. 77-632403; Defense Technical Information Center of Fort Belvoir: Virginia, WV, USA, 1977; ISBN 0-87944-080-5.

41. Tuncay, T.; Erbay, E. Primary objective of social work: Social justice from rhetoric to practice through empowerment. Soc. Darbas 2008, 7, 87-95.

42. Marin, M.R.P.; Ribes-Giner, G.; Pantoja Díaz, O. Enhancing Education for Sustainable Development in Environmental University Programmes: A Co-Creation Approach. Sustainability 2018, 10, 158. [CrossRef] 
43. Burns, D.; Heywood, F.; Taylor, M.; Wilde, P.; Wilson, M. Making Community Participation Meaningful; The Policy Press: Bristol, UK, 2004.

44. Cerqueti, R.; Correani, L.; Garofalo, G. Economic interactions and social tolerance: A dynamic perspective. Econ. Lett. 2013, 120, 458-463. [CrossRef]

45. Bjørnskov, C. Inequality, Tolerance, and Growth. Working Paper 04-8. Paper presented at Public Choice Society Annual Meeting, Baltimore, MD, USA, 11-14 March 2004.

46. Johansen, T.S.; Nielsen, A.E. Strategic stakeholder dialogues: A discursive perspective on relationship building. Corp. Commun. Int. J. 2011, 16, 204-217. [CrossRef]

47. Lu, S.; Au, W.T.; Jiang, F.; Xie, X. Cooperativeness and competitiveness as two distinct constructs: Validating the Cooperative and Competitive Personality Scale in a social dilemma context. Int. J. Psychol. 2012, 48, 1135-1147. [CrossRef]

48. Kwon, J.E.; Woo, H.R. The Impact of Flipped Learning on Cooperative and Competitive Mindsets. Sustainability 2017, 10, 79. [CrossRef]

49. Pysz, J.K. Opportunities for Cross-Border Entrepreneurship Development in a Cluster Model Exemplified by the Polish-Czech Border Region. Sustainability 2016, 8, 230. [CrossRef]

50. Phillips, F.; Hsieh, C.H.; Ingene, C.; Golden, L. Business schools in crisis. J. Open Innov. Technol. Mark. Complex. 2016, 2. [CrossRef]

51. Lee, K.Y.; Jung, K.H. Exploring institutional reform of Korean civil service pension: Advocacy coalition framework, policy knowledge and social innovation. J. Open Innov. Technol. Mark. Complex. 2018, 4, 1-23. [CrossRef]

52. Kim, D.S.; Lee, D.S. Impacts of Metacognition on Innovative Behaviors: Focus on the Mediating Effects of Entrepreneurship. J. Open Innov. Technol. Mark. Complex. 2018, 4, 18. [CrossRef]

(C) 2019 by the authors. Licensee MDPI, Basel, Switzerland. This article is an open access article distributed under the terms and conditions of the Creative Commons Attribution (CC BY) license (http://creativecommons.org/licenses/by/4.0/). 